\title{
Curbing violence against women: Time for a paradigm shift
}

\author{
Basil N Okeahialam* \\ Department of Medicine, Jos University Teaching Hospital, Jos, Nigeria
}

\begin{abstract}
Violence against women is abhorred by the World Health Organization and many female groups given the morbidity and mortality associated with it as well as the consequent poor quality of life. Though several approaches to eliminate it have been made, it has festered on. The author given his experience in the cause of research on premenstrual syndrome and hypertension in women is constructing a hypothesis that sees premenstrual syndrome as linked in some significant way to violence against women. This paper is suggesting a different approach, a paradigm shift to the subject; that of evaluating female victims of violence against women for premenstrual syndrome and offering treatment. Men in such relationships also need counselling and education to as it were "lengthen their fuses" and avoid shortcircuiting to explosion with the slightest provocation.
\end{abstract}

Violence against women (VAW) especially in the realm of intimate partner violence (IPV) borders on human right violation of women; and constitutes a major health problem. The World Health Organization (WHO) [1] estimates that about a third of women experience violence in their lifetime. Such experiences adversely affect physical, mental sexual and reproductive health; and put the afflicted in need of health services with huge financial burden. Quality of life (QOL) suffers as a consequence. VAW is usually seen in the context of men visiting it on women, ignoring the fact that it has been recorded in lesbian and other all-female relationships [2]. This position tends to focus attention on characteristics of men who perpetrate this act. Whereas it is not out of place to focus on men being the physically stronger, a paradigm shift is called for. This is because all-female intimate relationships are not spared. Again the author's experience in the course of researching into the relationship between premenstrual syndrome (PMS) and arterial hypertension in women are full of anecdotes warranting the opening of this vista; and borders on PMS as a vulnerability factor. Annually the United Nations sets aside a day to create awareness of VAW and its consequences; calling for an end to it. The problem is likely to remain with us for longer if a slightly different perspective is not brought to bear.

Certain human actions and inactions make them vulnerable to some consequences. Several examples abound but suffice it to give a few of them. A young lad clumsy in musculo-skeletal co-ordination is likely to be the one getting injured when at play with peers. An individual who is not circumspective but impulsive is the one likely to fall prey to fraudsters. Finally the disobedient and disrespectful child is the one likely to be left alone to learn by his or her own mistakes, while the obedient and respectful child gets gifts and mentoring. This is not an attempt to justify VAW or stereotype women, as it is bound to hurt the sensibility of feminists. It is rather a case of using personal experiences and anecdotes to construct a hypothesis which if proven is bound to mitigate the monster called VAW. A few case vignettes will come in handy here.

\section{Vignette 1}

Many years ago, a young doctor whose duty implies some days away at work on call duty got entangled with a charming young lady who could be marvelous on a good day. The relationship was however cyclically turbulent; and given away as female mannerisms of not wanting to come across as "cheap". On this fateful day he came home to his girl who despite knowing that he was on call, jumped on him demanding to know why he was returning late; tearing at him in the process. Attempts at easing off the grip and the question "what has come over you?" were all that caused her to visit arson to the house and leaving. One week later she returned looking desirable and asking to be let in; but it was all over. Had the man not restrained himself, it would have been a scene of VAW.

\section{Vignette 2}

In the course of evaluating a female hypertensive with features of PMS, the women in an attempt to give emphasis to the author's question on mood, angry outbursts and irritability said, "Doctor I am plain nasty at those times". She continued with "That he does not beat me up surprises me". "When he walks calmly away saying that I must be in my bad moods, I would burst into tears, go on my knees and thank God for giving me such a husband". "However deep down I worry about when I would exhaust his patience". "Consequently I asked to take a holiday hoping to find a solution to my cyclical problems away from him". There are several incidents of VAW averted by the calm disposition of the man.

${ }^{*}$ Correspondence to: Basil N Okeahialam, Department of Medicine, Jos University Teaching Hospital, Jos, Nigeria, Tel: +234-805-1499-271; E-mail: basokeam@yahoo.com

Key words: premenstrual syndrome, violence against women

Received: January 21, 2019; Accepted: February 04, 2019; Published: February 08, 2019 


\section{Vignette 3}

A man was once presented with complaints of how nasty his wife had been to neighbors. She was known to be cantankerous and neighbors wondered why her husband had not taught her a couple of lessons. The man pleaded that it was a cyclical routine at home, asking the complainants who attended the same church with his wife if their clergy did not preach good neighborliness. His wife was very religious and the contrast in her conduct put him off being religious. He prayed the neighbors to ignore those irritations the same way he had managed to cope at home. This is another situation where a man's disposition saved constant VAW.

\section{Vignette 4}

A working-class woman was periodically verbally abusive to her husband. This went on without response until the man lost his job. Frustrated, economically dependent on his wife and low on patience, he no longer condoned those verbal outbursts. He now saw those irritating outbursts as arrogance based on economic advantage. On this fateful day, he jumped on her visiting physical trauma on her. That was VAW, and the beginning of what became marriage failure with huge physical and mental toll.

Understanding IPV is said to be difficult, more than studying a disease [3]. Many things are at play and it would be too simplistic to posit that it is always the fault of women. It is more complex than that. Socio-cultural characteristics like ethnicity, religion and spousal age differences have been considered [4]. Men who visit VAW on their significant others are known to have low education, history of childhood maltreatment, exposure to domestic violence while growing up, alcohol and substance abuse issues as well as attitudinal acceptance of violence as a way of putting their women where they belonged [5]. This is a typical phenotype for those who have a short fuse [6] that when PMS supplies the spark would see them blowing up. The above features appear incomplete to the author. Though harsh economic conditions can strain family dynamics and create a favorable ambient for quarrels [7], economically subordinate position in the home will also reduce a man's threshold for VAW. In Africa, infertility will also feature and has been reported [8]. It is believed that infertility is squarely a female problem; and the man perceiving childlessness and its attendant societal low esteem to be from his wife will visit VAW on her. These are interestingly what education, family counselling and attitudinal change can deal with. For women it is felt that low education and economic status, physical abuse in childhood, exposure to mother abuse early in life, cultural acceptance of unequal gender norms are predisposing factors. The role of education is two pronged. When low and associated with economic dependency, unmet domestic needs give rise to quarrels and violence. When high, there is economic emancipation and some independence. The woman becomes assertive and may not be willing to accept the cultural norm of male dominance in marriage [4]. There is however, one that in the author's view has been ignored for long; and that is PMS [9].

In a literature of the Australian Institute of Criminology - Trends and Issues in Crime and Criminal Justice it was stated that the reality of the disorder PMS and its consequence in a small minority of women should not be ignored [10]. It drew from the warning of the moody nature of women in a writing by Sermonides, a Greek philosopher [11] thus ...... One day she is all smiles and gladness. A stranger to the house seeing her will sing her praise......But the next day she is dangerous to look at and approach; she is in a wild frenzy.....Savage to all alike, friend or foe.

\section{In the case vignettes}

1. The woman acted out of character in a manner potentially provocative of VAW. The man was shocked and so ended the relationship

2. The woman realized her helplessness with certain periodic behaviors and wondered for how long she would escape VAW. She would pray for the man in her "off period" and opted to temporarily relocate to seek help.

3. A man's calm disposition led him to adjust and permanently ignore his wife's cyclical misdemeanor.

4. An economic reversal led a man who would usually tolerate his wife's cyclical irritation to lose his calm and visit her with VAW.

Though the family violence perspective views intra family conflict as universal and inevitable with no basis of individual pathology [12], it is one's humble submission that incidence of VAW is tied in some way to the biology of the woman regarding the presence of PMS or more typically premenstrual dysphoric disorder (PMDD). These were captured in some works that showed PMS leading to marital discord and loss of relationships on the one hand and their (PMS sufferers) being more verbally critical and physically violent towards their family members $[13,14]$. It has been posited that during the menstrual period some women with PMS experience a feeling of indescribable tension, irritability and a desire to find relief by foolish and ill - considered actions [15]. These features usually cluster in the luteal phase of the menstrual cycle. PMS and especially PMDD make women act out of character and figuratively speaking turn them into raging animals [16]. No insult or humiliation is intended. They may at such times become impatient with and confront established norms that would accept male dominance, in such ways that attract violence.

Some authors believe that wife beating may be triggered by behaviors brought about by irritability in the premenstrual period [17]. Therefore, the context in which VAW occurs is important. It has been said that in measuring domestic violence, the context in which it occurs should be considered [18]. Going further, the author alluded to the opinion of feminist advocates that all acts of intimate partner violence especially perpetrated by men on women amounted to battery; in an attempt to exert power and control, not minding that some of those were actually provoked. Some women attribute their violence in the setting of IPV to uncontrollable anger [19] which is a feature of PMS [15]. Another group of women reported expression of anger, frustration and emotional dysfunction as being predictive of their perpetrating IPV [20]. Since violence begets more violence, their vulnerability increases.

The recommended difference in approach would be to view VAW from a PMS prism and assess victims of VAW for PMS. When discovered, appropriate treatments would reduce their vulnerability to VAW and mitigate this public health problem with huge morbidity and potential mortality. Husbands in such relationships would also need counselling to become more tolerant to their significant others and avert such resort to battering. For them the cliché that "Real men do not batter women" should become a life-style. That in the author's humble opinion is the path to navigate.

\section{References}

1. United Nations (1993) Declaration on the elimination of violence against women. New York.

2. Girshirk LB (2002) No sugar, No spice. Reflections on Research on women to women sexual violence. Violence Against Women 8: 1500-1520. 
3. Jewkes R (2002) Violence Against Women III. Intimate Partner Violence: causes and prevention. Lancet 359: 1423-1429. [Crossref]

4. Adebowale AS (2018) Spousal age difference and associated predictors of intimate partner violence in Nigeria. BMC Public Health 18: 212. [Crossref]

5. WHO (2017) Violence against women. Intimate partner violence and sexual violence against women. Fact Sheet. Available from: http://www.who.int/mediacentre/ factsheets/fs239/en

6. Lever J (1981) The Premenstrual Tension. McGraw-Hill. Toronto. pp: 63.

7. Bamiwuye SO, Odimegwu C (2014) Spousal violence in sub-Saharan Africa: does poverty- wealth matter? Reprod Health 11: 45. [Crossref]

8. Aduloju PO, Olagbuji NB, Olafinbiyi AB, Awoleke JO (2015) Prevalence and predictors of intimate partner violence among women attending infertility clinic in South-West Nigeria. Eur J Obstet Gynaecol Reprod Biol 188: 66-69. [Crossref]

9. Obindo TJ, Okeahialam BN, Ogbonna C (2010) Violence against women: Is premenstrual syndrome a vulnerability factor? Int J Acad Res 2: 153-155.

10. Eastel PW (1991) Women and Crime. Premenstrual issues. Trends and Issues in Crime and Criminal Justice.

11. Trimble J, Fay M (1986) PMS in today's Society. Hamline Law Review 9: 183-191.
12. Gelles RJ, Straus MA (1979) Determinants of violence in the family: towards a theoretical integration. In Burr WR, Hill R, Ivan Nye F, Reiss IL (eds). Contemporary theories about the family. The Free Press. New York. pp: 549-581

13. Johnson SR (1987) The epidemiology and social impact of premenstrual symptoms Clin Obst Gynaecol 30: 367-376. [Crossref]

14. Keye WR (1986) General evaluation of premenstrual symptoms. Clin Obst Gynaecol 26: 396-405. [Crossref]

15. Kendal K (1991) Masking Violence against Women. The case of Premenstrua Syndrome. Canadian Women Studies 12: 17-20.

16. Benedek E (1985) Premenstrual syndrome: a new defense? In J. Gold (ed). The psychiatric implications of menstruation. American Psychiatric Press Inc. Washington.

17. Berger G (1984) PMS - Premenstrual Syndrome. Hunterhouse. Claremont CA. pp: 29.

18. Myhill A (2017) Measuring domestic violence: Context is everything. $J$ Gender Based Violence 1: 33-44.

19. Caldwell JE, Swan SC, Allen CT (2009) Why I hit him. Women's reasons for intimate partner violence. J Aggress Maltreat Trauma 18: 679-697. [Crossref]

20. Stuart GL, Moore TM, Gordon KC, Hellmoth JC, Ramsey SE, et al. (2006) Reasons for intimate partner violence perpetration among arrested women. Violence Against Women 12: 609-621. [Crossref]

Copyright: (C2019 Okeahialam BN. This is an open-access article distributed under the terms of the Creative Commons Attribution License, which permits unrestricted use, distribution, and reproduction in any medium, provided the original author and source are credited. 